\title{
Assisted Reproduction across Borders
}

\author{
Merete $\mathrm{L}^{1 *}$ and Nina $\mathrm{L}^{2}$ \\ ${ }^{1}$ Norwegian University of Science and Technology, Norway \\ ${ }^{2}$ Linköping University, Sweden
}

Submission: October 18, 2017; Published: February 06, 2018

*Corresponding author: Merete Lie, Norwegian University of Science and Technology; Email: meretelie@ntnu.no

\section{Opinion}

Assisted reproductive technologies (ARTs) are now positioned as a means to achieve the "democratization" of childbirth, including same-sex and single-parent families. In a global perspective, however, the very same technologies have enforced new inequalities the way they have become available on a global, commercial market. In some countries, predominantly secular western democracies, it has been politically possible to raise demands for equal access to ARTs, regardless of gender or sexual identities, even though exclusionary policies and practices of assisted reproduction are still very much on the agenda. Still, it is an inevitable paradox of the contemporary, neoliberal, and globalized world that ARTs have created new possibilities for some people as recipients of gametes, cures, and gestational labor, whereas others, in particular women in precarious situations, have become the providers.

Generally, his takes place in a world where intersections between gendered and geopolitical inequalities and power differentials have mutually reinforced each other. At present, ARTs are no longer "new technology" or cutting-edge science but are regarded, in large parts of the world, as mundane practices. This can be exemplified by how, in Norway, the general understanding of involuntary childlessness is that this definition only applies after you have tried IVF, whereas previously, you were perceived as involuntarily childless when accessing a fertility clinic [1]. In other words, in some contexts, some ART procedures are now included in the normal repertoire of getting pregnant. However, the broad term of assisted reproductive technologies includes a wide spectrum of techniques, of which some have been working successfully for many years and are available globally, while others such as surrogacy are highly contested.

When the introduction of and access to ARTs become topics of public debate, this generally concerns medical practice and ethics. The importance of cultural aspects, such as religion, myths, and origin stories is seldom mentioned. Social and cultural aspects, such as traditions relating to religion, kinship, gender relations, and sexualities both affect ART practices and are affected by them.

In a global perspective, legal regulations, norms and practices of ARTs vary in relation to the socio-cultural context within which they are introduced. Moreover, different legal frameworks regulating access to ARTs function as cultural markers emphasizing distinctions that a nation may want to make visible. Some European countries, for example Germany, have comparatively strict laws on ARTs that have been supported by strong arguments against eugenics, as a counter-reaction to the country's Nazi past. Another example is Ireland's strong prolife attitudes, anti-abortion laws, and a "moral veto" of ART practices [2]. Thus, policies regulating the life sciences have been incorporated into nation-building projects [3]. As such, the varying legal regulations do symbolically illustrate what a nation stands for and contribute to the cultural image of a nation -in terms of depicting itself as a nation of a high moral standard, or alternatively, as a liberal nation with individual freedom of choice. ARTs are accessible worldwide but definitely not by everyone. We have aimed at highlighting how access to ARTs includes many different elements; among them are the legal regulation that takes place on a national level, a rapidly developing fertility industry in a global marketplace and, not least, the cultural norms and traditions that are vital to varying practices worldwide.

\section{References}

1. Lie M, Malin NR, Kristin HS (2011) Reproductive Imaginations: Stories of Egg and Sperm. NORA: Nordic Journal of Feminist and Gender Research 19(4): 231-248.

2. McDonnell (2017) The Veto of Moral Politics: The Catholic Church and ARTs in Ireland, In: Lie M, et al. (Eds.) Assisted Reproduction Across Borders. Feminist Perspectives on Normalizations, Disruptions and Transmissions. USA.

3. Jasanoff S (2005) Designs on Nature: Science and Democracy in Europe and the United States. Princeton: Princeton University Press. 
(C) (i) This work is licensed under Creative BY DOI: $10.19080 /$ GJORM.2018.03.555609

\section{Your next submission with Juniper Publishers will reach you the below assets}

- Quality Editorial service

- Swift Peer Review

- Reprints availability

- E-prints Service

- Manuscript Podcast for convenient understanding

- Global attainment for your research

- Manuscript accessibility in different formats ( Pdf, E-pub, Full Text, Audio)

- Unceasing customer service

Track the below URL for one-step submission https://juniperpublishers.com/online-submission.php 